\title{
The Past as Science: Romanian Cartography at the Paris Peace Congress of 1919
}

\author{
Silviu ANGHEL \\ Mappamundi, Bucharest, Romania; silviuanghel2011@yahoo.com
}

Abstract: Romanian cartography at the Paris Peace Conference has so far received very little attention. Nevertheless, Romanian scholars produced tens of maps to support Romanian claims, most of them ethnographic ones. Seen as unscientific in 1919, they were quietly brushed aside. The present article argues that Romanian maps of 1919 displayed the same ideas found among Romanian elites. Ethnographic space was for them not just a matter of graphic representation of census results, but also the historical development of ancient and modern Dacia. Romanian cartography was congruous with Romanian culture in a wider sense. The article will review these ideas and then discuss their impact in Paris in 1919 and for Romanian culture since then.

Keywords: Romanian ethnographic maps; ethnographic cartography; representations of power; cartography at the Paris Peace Conference of 1919.

\section{Introduction}

Over the past decades a new wave of cartographic thinkers, which came to be known as the school of critical cartography, has created a new discourse that views maps not as objective representations of a scientific nature but as 'knowledge as power' (Crampton, 2006). Maps are seen as the result of "deliberate distortions for political purposes" (Harley 2001, p. 63). This interpretation is based on two fundamental hypotheses. First, the cartographer does not create alone, in isolation. Maps are expensive to produce and publish; they are the result of a whole network of technicians and political funders. "Behind the map maker lies a set of power relations... the cartographer has never been an independent artist, craftsman or technician", wrote Harley (Harley 2001, p. 63) Second, decisions of scale, subjects, or iconology are made consciously and unconsciously based on their 'relevance' which is itself a cultural construct. Maps, like any other cultural product, are very much a result of the present, imbued with the same interpretation of the world and the past. The rarely quoted masterpiece of Wilkinson (1951) on the ethnographic maps of Macedonia shows how maps were continuously changed to adapt to a series of beliefs that changed over time.

The present article discusses Romanian cartographic activity at the 1919-1920 Peace Conference in Paris from this perspective. At the time, Romanian cartography for the Peace Conference was poorly received and considered unscientific. The present article will argue that in the eyes of Romanian map makers, these maps were scientific. The article will argue that Romanian maps contain the same message as that of historians or other academics at the time. Romanian culture used a different construct of ethnicity and history. It was this construct that was seen by Western scholars as unscientific.

In the past thirty years historians of cartography have dedicated an increasing number of articles to the cartography of the Paris Peace Congress of 1919 (Bowman 1921; Bariéty, 1996, 1997; Boulineau 2001a, b, 2008; Bowd, 2011, 2012; Ginsburger, 2010, 2015a, b, 2016a, b; Hallair, 2007; Palsky, 2002, 2015; Prévélakis, 2000; Suveica, 2017; Ter Minassian, 1997, 2002; Société de géographie de Paris, 2015. On Hungarian cartography see especially Ablonczy, 2007, and Ginsburger, 2016a). A great deal has been written on French, English, American, Hungarian or Serbian geographers, and cartographers, yet very little information exists on the Romanian cartographic efforts. By Romanian we mean the activity of Romanian-based scholars, working in Romania or 
elsewhere, closely or loosely connected with the efforts of the Romanian delegation at the Peace Conference.

In fact, Romanian cartography was very active in 1919. Romanian scholars from various fields produced maps and wrote geographical arguments which aimed to support Romanian territorial claims. The present article, a preliminary report of the research conducted into Romanian cartography in 1914-1919, will describe a few of those efforts.

\section{Maps and the Peace Conference. The Romanian story}

Human geography played an important role in the Peace Conference. Decisive in border tracing or not, the ethnographic factor was always present in the discussions. Human geography existed in two forms: a graphic one, maps, and a written and statistical one, above all census results and population analysis. Who were the cartographers and geographers who were influential at the Peace Conference? They were for the most part well-established academics, whose work was directly or indirectly read in Paris. This was particularly true of the borders of Eastern Europe, which were mostly decided not by politicians but in commissions of technicians, called experts. These were either experts or close students of cartography and human geography.

The case of the Serbian geographer Jovan Cvijić is particularly revealing. Nicolas Ginsburger (2016b) traced his activity in support of Serbia's war aims. Cvijić spent the war in Paris where, by lectures and publications, he made himself the centre of a network of knowledge about the Balkans. He became highly influential both among Western scientists and politicians. Cvijić's success was based above all on his scientific reputation. When the war started, he had already achieved an enviable reputation among Western scholars. He carefully cultivated his academic position and his connections. As the First Balkan war led to a hunger for scientific knowledge on the region, Cvijić became not only a good source but the only reliable source of information (Cvijić 1918, 1919; see also Lederer, 1963, and Albrecht-Carrié, 1938).

Although Cvijić maintained a high scientific standard in his publication, he also managed to keep up with changes in Serbian foreign policy, even when this policy shifted dramatically. Wilkinson's magisterial study of the Ethnographic maps of Macedonia shows that Cvijić's maps changed during the Balkan Wars mirroring Serbian foreign policy (Wilkinson, 1951; White, 2000). This was not due to disingenuousness on Cvijić's part. We argue that the field of ethnographic cartography as a whole was closely connected with politics. It was the science of border tracing, one closely linked with nation-building and with the diplomatic situation, and with nationalistic discourse. A simple survey of ethnographic maps will show that they were not published uniformly in time but they clustered around wars and peace conferences. Political pressures, as well as scientific acumen, were both equally in the background of ethnographic cartography.

The success of Cvijić brings into perspective the activities of Romanian cartographers and geographers. Few can recall the name of a single Romanian expert who participated in the peace conference and even fewer can trace his or her influence (Seton-Watson, 1981; Sandu, 2006). It's often said that Romanian politicians relied on Emmanuel de Martonne. Yet there is no evidence that the Romanian delegation relied on de Martonne. On the contrary, they commissioned a plethora of maps and ethnographic studies, some of which made it to Paris and were either used in the debates or presented to Western participants. De Martonne is famous not only in the scholarly world. He has been the focus of numerous celebrations in Romania itself. In 1973 Ceausescu's regime celebrated a centenary from his birth. More recently the French cartographer is the object of no fewer than three statues raised during the centennial commemoration of Trianon, at Cluj, Alba Iulia, and Oradea. De Martonne's prominent role in what is otherwise a national celebration illustrates how absent Romanian scholars are. 
Romanian cartographers were present in Paris and they produced a large number of materials. They focused on those claims which were not recognized by the international community, namely the Western Banat and the Hungarian-Romanian border (Spector, 1995; Boulineau, 2001a, 2001b). Yet even from 1919, their results were not well received by Western geographers. De Martonne comments in a letter to his friend Vâlsan dated $19^{\text {th }}$ of January 1919:

"I have just had news of Mr. Lapedatu. He tells me that you are still sick and cannot stand the journey to Paris...I wish only that your compatriots who have established themselves here (i.e. to Paris, n.a.) to create 'propaganda' would show more measure and less ambition. They publish brochures which do more damage than good and maps about which I am obliged to say that they are false. What a pity again that you could not come". (Bowd, 2012, pp. 55-56)

It is often easy to spot 'propaganda' in others. Creating propaganda is an irregular verb, just like being eccentric or cunning - I create science, you create propaganda. Displaying a cult of science often found in scholarly circles, De Martonne displays a binary view of ethnographic cartography: there are those who produce science and those who produce 'propaganda'. Equally, in the eyes of the Romanian map makers, their maps were not propaganda but science. Propaganda was found in all maps, including those of Cvijić of de Martonne himself (Palsky, 2002). On a deeper level, all scientists were conscious of creating propaganda. Just as Cvijić was careful to distribute his material to relevant diplomats in Paris, de Martonne, in the same letter we have just quoted, admits to being involved in propaganda:

"I am still in relation with the American experts. They have all the reports, the maps, etc. (i.e. written by de Martonne, n.a.). I was even able to offer advice to them and I furnished our (i.e. French, n.a.) Minister of Foreign affairs a series of reports to study the different Romanian claims". (Bowd, 2012, pp. 55-56)

The chief creator of Romanian propaganda, in this case, was the very Alexandru Lapedatu, whom de Martonne mentioned. A historian and close friend of Ion I.C. Brătianu he was sent to Paris in January 1919 as the main creator of material for Romania's cause. Symptomatically he was a historian and not a geographer or cartographer. Having arrived in Paris at the end of December 1918 (Wild, Wild, \& Ardeleanu, 2018) he would eventually start working with a graphic designer and Professor of Belles Artes in Iasi who was already in Paris at the time., A.D. Athanasiu. The two would create the official maps presented by the Romanian delegation at the Peace Conference. It was Athanasiu who drew the maps and Lapedatu who decided the content. Athanasiu had already been commissioned by the Romanian National Council or more precisely Le Comité National de l'Unité Roumaine (Spector, 1995, p. 53) in December 1918 to draw maps promoting Romania's cause, maps which were printed in as many journals as possible, especially in the newspaper of the comity, La Roumanie. Among the intellectuals active in this council were Nicolae Titulescu, Vasile Lucaci, Octavian Goga, and in the first phase Take Ionescu. Most maps created by the Romanian delegation at the Peace Conference only bear the name of Athanasiu, but one must bear in mind that besides him there was a creator of map content, often but not exclusively Lapedatu, whom we will call the map maker.

Not only Romanian cartography left a bad impression in Paris. "Benes has masses of sketch maps, designed for the use of children, or the Conseil des Dix" (italics by us, n.a.), wrote Harold Nicolson in his diary on February the 7th 1919 (Nicolson, 1933/1966, p. 273). Children and politicians had the same level of understanding, according to Nicolson. Essentially this is the same critique as de Martonne's: Nicolson sees Czech maps as unscientific. Czech maps and documentation were apparently the models of Lapedatu's propaganda effort (Wild, 2018, p. 10).

De Martonne does not name the map he is referring to, because it was clear to anyone who read the newspaper La Roumanie. In this newspaper, several maps were published in 1918 and 1919. Since de Martonne wrote his letter on January 19, the map he 
criticized must date to before this date. We know of a map drawn by Athanasiu in December 1918. This is very probably the map de Martonne criticizes in his letter. It is called the 'Ethnographic Map of Regions Inhabited by Romanians'. Just as it will be the case a few months later when he cooperated with Lapedatu, in this map Athanasiu was not the creator of map content. He is only the map drawer. The creator, whom we can call 'the map maker', was one or more of the intellectuals active in the Romanian National Council at the time. The ideas are nevertheless not original but ever-present in Romanian contemporary literature and thought.

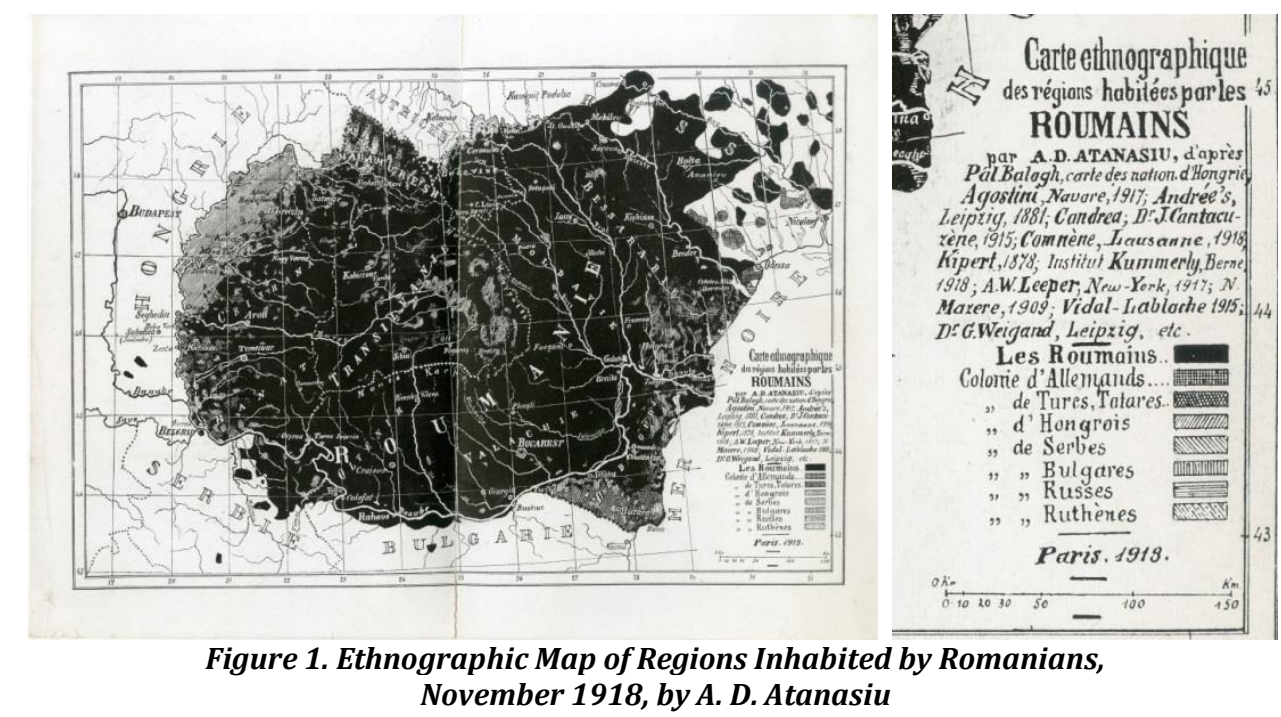

Printed in b/w, the map was clearly designed to be published in journals. It reveals, upon closer inspection, a lot about Romanian ethnographic cartography in 1919. The fact that the map was not created by a cartographer or at least a geographer is quite visible. The map quotes, in an all-out effort at captatio benevolentiae, a bewildering variety of sources: Romanian - Nicolae Mazere, Hungarian - Pál Balogh, German - Kiepert, French - Vidal-Lablache, Italian - Istituto Agostino di Navare, English - Leeper. All these maps are quoted, but not really used in the map. For example, the 1909 Romanian map of Mazere, which covers only the province of Transylvania proper. Mazere used the Hungarian 1910 census data and the Székelys in the middle of the principality are much more visible than on Athanasiu's map. It is the 'etc.' the map adds at the end of the list which shows that in the map makers' view all these sources all show the same thing what the Romanian map maker wanted them to show. In other words, the map is based on a superficial reading of other maps, in which they are only used as an illustration for what one has to say even if or rather in spite of the fact that they do not really illustrate correctly.

For many, an ethnographic map is an instrument of the present, based on the most recent statistical data. Yet our map maker has the past in mind, as is revealed in the second half of the legend. Romanians, he states, are the indigenous population while all the others are 'colonists'. "The Romanian language can be heard in all the region which was once called Dacia" stated the 1914 edition of the $8^{\text {th }}$ grade Romanian Geography book, by G.M. Murgoci and I. Popa-Burcă (Murgoci \& Popa-Burcă, 1914, p. 3). The use of the singular, 'region' referring to ancient Dacia was changed by our map maker to the plural, 'regions', when speaking of the $20^{\text {th }}$ century. Still, it described the area between the Tissa, the Dniester, the Danube, and the Black Sea. On the map, the black colour, referring to Romanians covers space South of the Danube and East of the Dniester. In the West, it firmly stops short of the Tissa, but on a line identical to that claimed by Ion I. Brãtianu in his 1916 secret treaty with the allies.

The map reveals a fundamental belief of the Romanian delegation to the Peace Conference. To them, ethnographic maps were not only graphic spatial representations 
of census results. Rather, they were a mixture of historical and ethnographic representations. Romanian claims hinged not only on the present, i.e. on the population of Dacia, but also the past, on the inheritance of Dacia. The two concepts had merged to the point to which they were indistinguishable. This ethno-historical concept was a superficial reading of either ethnography or history which used, uncritically, historical arguments to justify ethnographic terms and vice versa. So on the map presented above uses historical concepts (i.e. colonists) to describe an ethnographic reality and the geography book of G.M. Murgoci and I. Popa-Burcă used an ethnographic reality (i.e. the Romanian language) to describe the historical concept of Dacia.

In the same schoolbook, called 'Romania and the Countries Inhabited by Romanians', the concept of 'countries inhabited by Romanians' and that of 'regions inhabited by Romanians' are used interchangeably. The term 'country' refers to an area fixed by historical borders, such as Transylvania, the Banat, etc. (on the teleological implications of 'country' see Coman, 2006). The term 'region' refers more fluidly to the area where Romanians are in a majority. Or so it should. In fact, the meaning of the two was used regardless of nuances. In chapter 1, called 'Romania and the Countries inhabited by Romanians' (italics by us, n.a.), Murgoci and Popa-Burcă present a simple ethnographic map labelled 'The Position of Romanians in Europe. Hachured regions are those inhabited by Romanians; the dark colour is Romania' (italics by us, n.a.). The countries are Banat, Crisana, Maramures, etc., i.e. all of Dacia between the Tissa and the Dniester. The hachured area is that thought by them to be inhabited by Romanians in the present and varies from one edition to the other (we present the $1^{\text {st }}, 1902$ edition and the $6^{\text {th }}$, 1914 edition). In neither case does it cover all of Dacia. Nevertheless, the two notions, that of regions and that of countries inhabited by Romanians are presented as congruous.

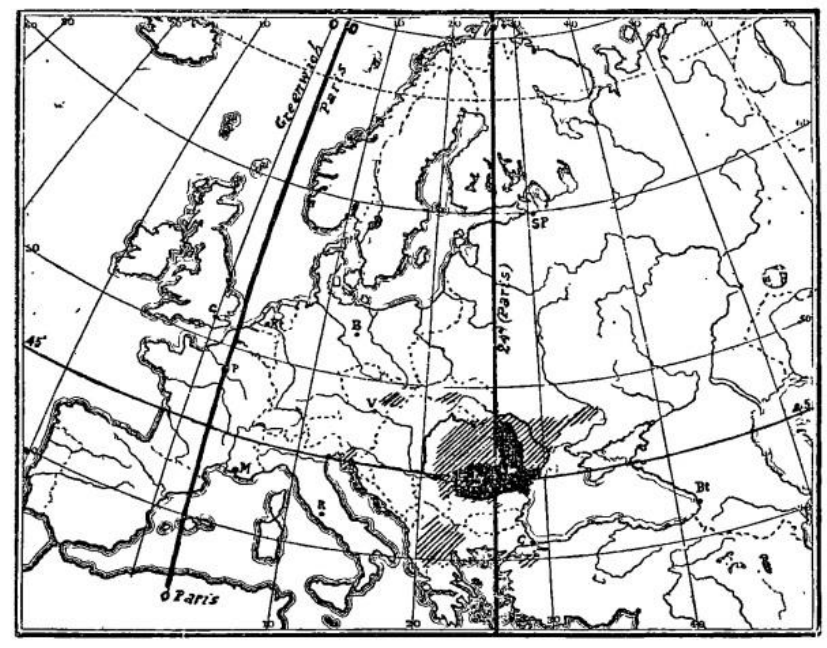

Fig. 1. Posiţiunea Romanilor in Europa. Regiunile lineate sunt cele locuite de Românǐ; pata négră e România

Figure 2. The position of Romanians in Europe.

The hachured regions are those inhabited by Romanians: the black colour is Romania (Murgoci \& Popa, 1902, p. 5) 


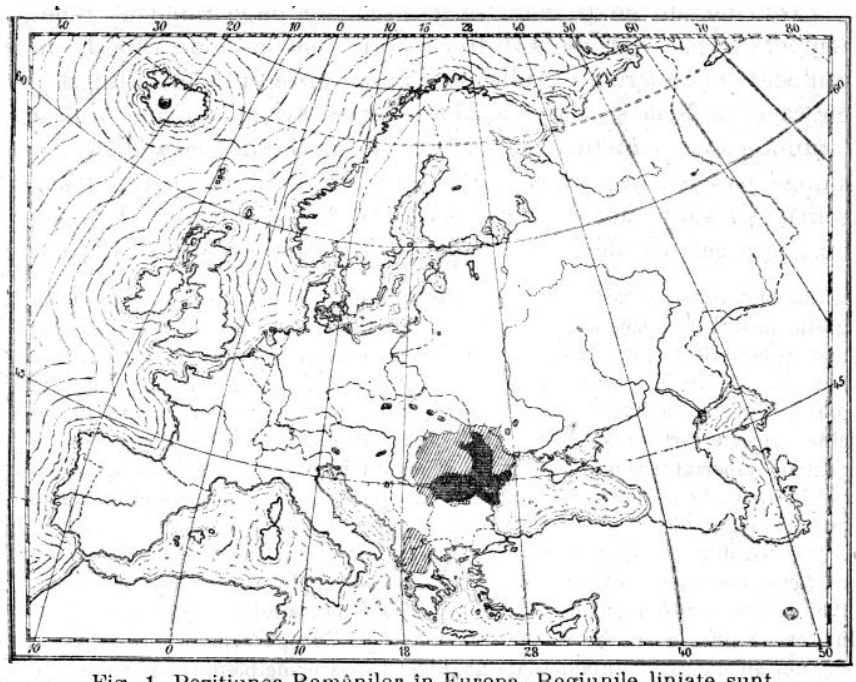

Fig. 1. Poziţiunea Românilor în Europa. Regiunile liniate sun cele locuite de Români; pata mai închisă e România

Figure 3. The position of Romanians in Europe.

The hachured regions are those inhabited by Romanians: the black colour is Romania (Murgoci \& Popa, 1914, p. 5)

This type of understanding of ethnographic maps was widespread in Romanian society. In 1919 Ion Antonescu, of later World War II fame, wrote a book called the Romanians. Their origin, past, sacrifices and rights'. The book argues that Romanians are entitled to all the territory they claimed. It appends an ethnographic map, a reprint of a small-scale Ethnographic map of Meyer. In chapter 2, called 'Ethnographic Arguments, Antonescu exhorts the reader to study carefully the map (Antonescu, 1919, p. 36). "Open the map in Annex II", he argues, "and you will note at once how numerous Romanians are and how close their ranks". (Antonescu, 1919, p. 37) Yet the map does not support Romanian claims, for example, in the Western Banat or Southern Bessarabia.

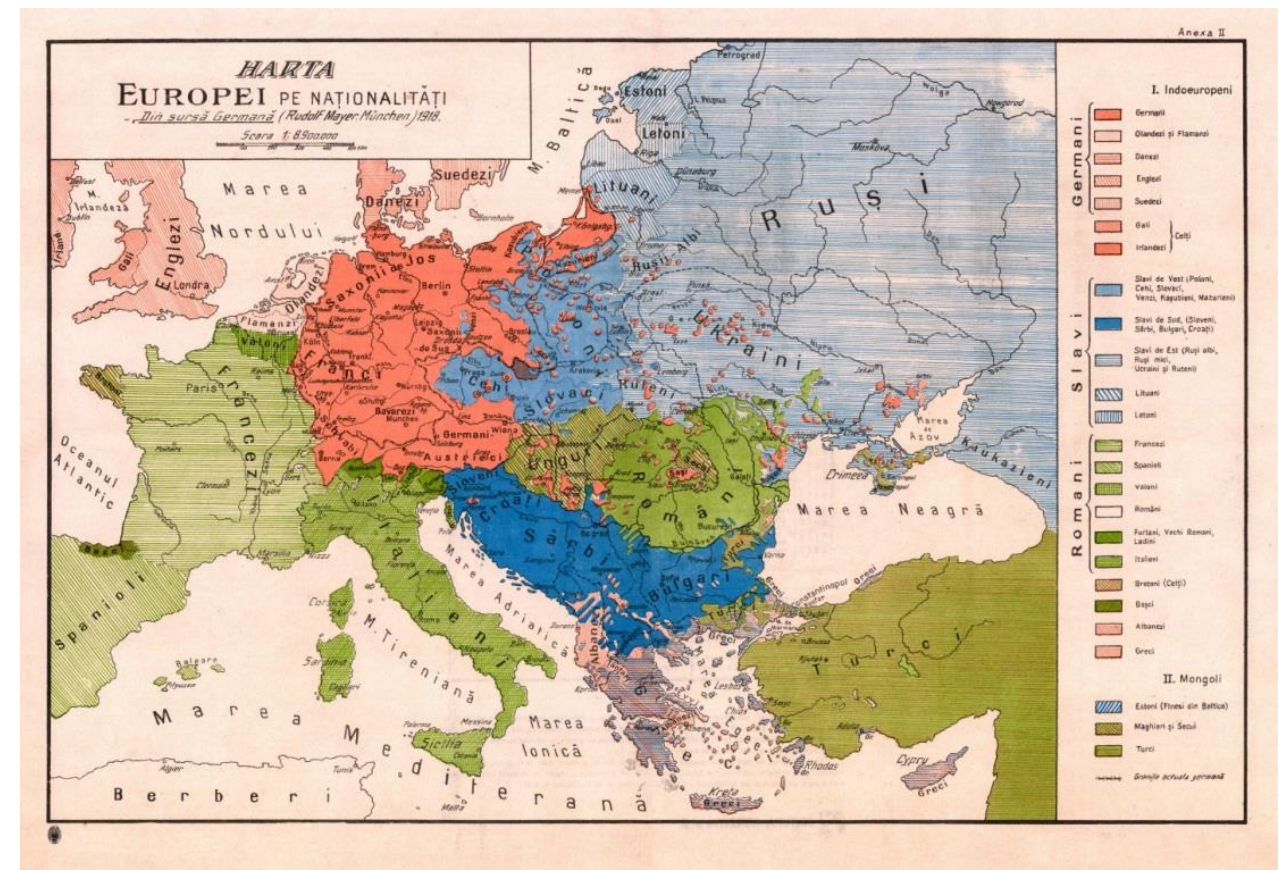

Figure 4. The Map of Europe

based on Nationalities from a German Source (Rudolf Meyers, Munchen) 1918

(Antonescu, 1919, Annex II) 
A little further, Antonescu again calls upon maps:

"Compare, against each other, all the ethnographic maps which have ever been made, at any time, both by our enemies, directly interested in hiding reality and by impartial seekers of truth and you will see that the breath and uniformity of the Romanian block are recognized by all" (italics by author, n.a.) (Antonescu, 1919, p. 37).

In Antonescu's view, all ethnographic maps show the same thing. This is the same reading of ethnographic maps displayed by the Athanasiu map and criticized by de Martonne. Yet his interpretation that these maps are 'false' does not help us understand the thinking of Romanian map makers in 1919. Antonescu did not change Meyer's map, he presented it in good faith claiming that it supported Romanian claims. The same was true of the map makers behind A.D. Athanasiu. All those maps they referenced may have varied in detail, but overall they presented the same conclusion if read with the ethnohistorical lenses they used.

None of the maps or map makers I have discussed so far was a professional cartographer. They did exist, although were not active in Paris at the time. De Martonne's letter quoted above laments the fact that George Vâlsan would have done a better job. Vâlsan had been injured in a train accident during the war. Another cartographer was Nicolae Mazere, one of the sources mentioned in Athanasiu's map. He had corresponded with de Martonne ten years before when he had published an excellent ethnographic map of Transylvania (Mazere, 1909a, b). His map used a large scale and pie charts to show every separate town in Transylvania. It was one of the sources quoted by de Martonne in creating his own map (De Martonne, 1921, p. 89, n.1). Mazere's work was, for 1909, a monument of erudition (Anghel, 2021). Yet as Transylvania proper was not under discussion in Paris, but rather the outlying provinces of Banat, Crișana, and Maramureș, Mazere's map did not play an important role. Alexis Nour's 1915 map of Bessarabia used a similar system to Mazere, and again it was used as a source by de Martonne (De Martonne, 1921, p. 89, n.2). Another example is that of Leonida Colescu, a statistician. In 1913 he published an excellent ethnographic map of Northern Dobroudja, again used by de Martonne (De Martonne, 1921, p. 89, n.4). Yet neither the ethnography of Bessarabia nor of Dobroudja was discussed at the Peace Conference (on Dobroudja see Ter Minassian, 2002. On Bessarabia see the recent work of Suveica, 2017). The only Romanian ethnographic map likely to have influenced in a great measure the scientific community in Paris would have been one of the outlying provinces of Banat, Crișana, and Maramureș. Nicolae Mazere had started such a project in 1909 but he had soon fallen ill. His project was taken over by Vasile Meruţiu who would later become a professor of geography in Cluj. Yet the effort by Mazere and Meruțiu, which involved lengthy trips in the field, was severely hampered by the war. Meruţiu would eventually publish his map late in 1919, clearly in a rushed state, but still too late for the peace conference or even for it to be used by de Martonne (Meruțiu, 1919a, b).

Yet these map makers were only starting to have an impact on Romanian society, culture, and politics in 1919. This applies to the Romanian delegation at the Peace Conference, where Brătianu only chose close collaborators of himself or the National Liberal Party. Many scholars, such as Simion Mehedinţi, a collaborator of the conservative opposition, were in 1919 ignored. But it also applies in a larger sense to Romanian ethnographic cartography as a whole. Of all those well-prepared maps we have mentioned above, only that of Leonida Colescu was fully sponsored by the Romanian state. Dobroudja, the subject of his map, was a territory in dispute by both Bulgaria and Romania and the latter was keen to prove that it was full of Romanians. Mazere, a highschool professor, undertook a costly and lengthy study of Transylvania out of his own funds and in his free time. His effort resulted in a combined ethnographic and topographic map of Transylvania. In 1911 his map was awarded a prize by the Romanian Academy, but the commission made it clear that they were most pleased with the topographic aspect of the work. The map did in fact, for the first time, put on a map the Romanian toponymy of Transylvania. The Academy provided some funding for Mazere 
to continue his work, but he soon fell sick. Meruţiu who also started as a highschool professor before moving to the Geologic Institute worked in equally difficult conditions.

Ethnographic maps and ethnographic discourse were quite common in Romanian culture. Most work however had been dedicated to the Koutzo-Vlachs spread throughout the Balkans. There the ethnographic argument was seen as the strongest argument. The 1878 map by Nicolae Densuşianu and Frédéric Damé was well-received both in Romania and abroad (Wilkinson, 1951, pp. 82-83). Ethnographic trips were organized in the Balkans to understand the extent, number, the need for schools or churches by several scholars. Yet the Romanian government, although it desired cultural autonomy and native-language education and religious rights for those populations at no point claimed the right to those territories. Even for Craina, a region bordering Romania there was no desire for annexation, neither in 1913 nor in 1919.

Romanian scholars seem to have viewed the two regions differently. While the ethnographic discourse applied to the Koutzo-Vlachs, the same was not true of DacoVlachs. In Romanian parlance, the region between the Dniester and the Tissa was associated not with ethnographic discourse, but with the ethno-historical one we have discussed above. This area was known first as Modern Dacia, but increasingly, on every map and in every geography schoolbook, as Romania and the Neighbouring Countries inhabited by Romanians. Yet in the first decades of the $20^{\text {th }}$ century, it was becoming apparent that this ethno-historical construct was being torn apart by the appearance of well-researched maps. When the war broke out, it soon became clear that territorial claims should be based on the present day and not the historical extent of the population to have any chance of success. In 1915 de Martonne published an article that defined what Romania's territorial claims should be, in his opinion. In Figure 5 we can see that de Martonne proposed a line (coloured in blue) that strictly followed the ethnographic situation which was drawn up according to the Hungarian census. This line fell slightly East of his own 1920 map. It was well East of the Tissa (coloured in red).
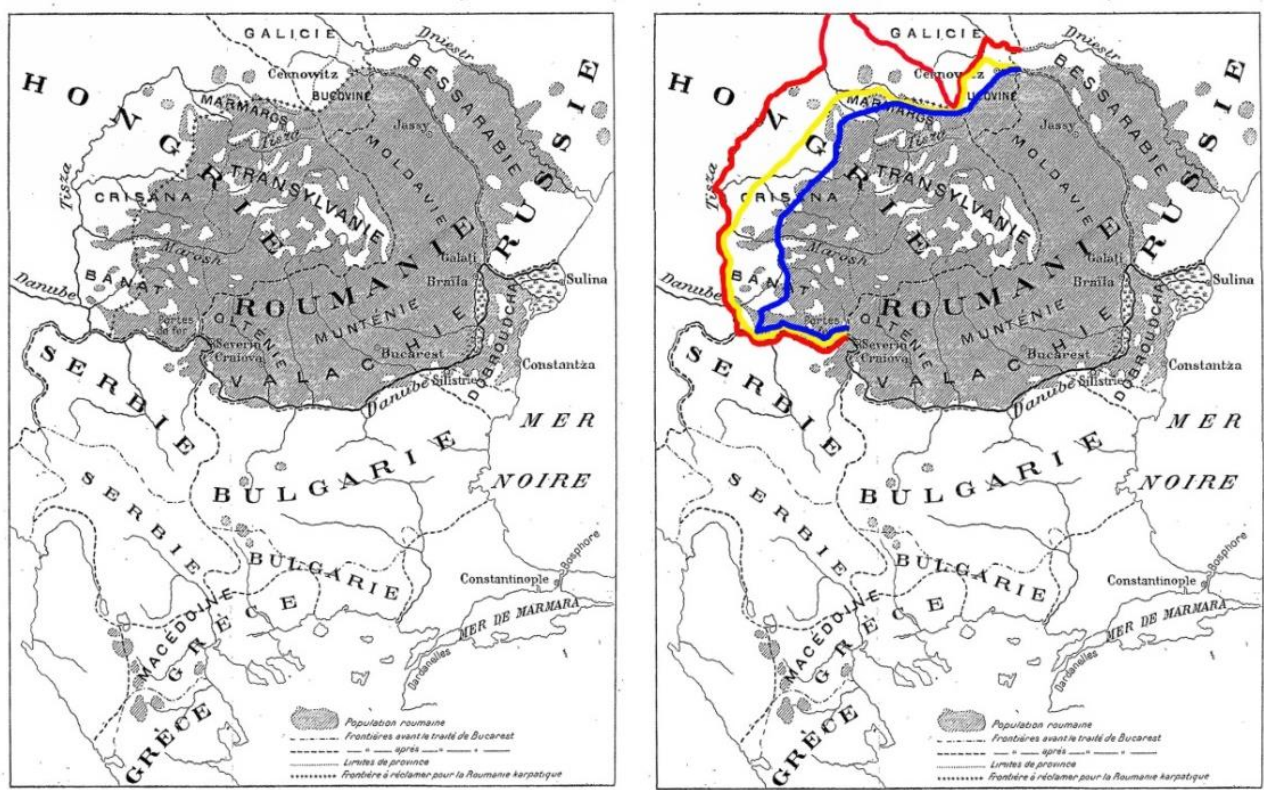

Figure 5. Emmanuel de Martonne, La Roumanie Carpathique, Paris 1915 (de Martonne, 1915a.) On the right is the same map with the superimposition of the various claims in 1915: the blue line: de Martonne's border of Carpathian Romania; the yellow line: Brătianu's border; the red line: the countries inhabited by Romanians. 
In 1914-1916, during the (at the time secret) negotiations between Brătianu and Sazonov, the line requested by the Romanian prime minister, although not grounded on an ethnographic line, still fell short of the Tissa (coloured in yellow on de Martonne's map). Brătianu's line cannot be explained by reference to any existing program of claims, either in historical or ethnographical terms. Nobody discusses it before the war. It probably shows hesitation, on his part to adopt the maximalist line of the Tissa, out of fear of rejection and the creation of a large irredentist Hungarian movement within the new borders.

In Romanian society, the start of the First World War signalled the start of serious civil strife for or against Romania's entry into the war. Many new maps with Romania's war aims were produced. Along with the traditional "Romania and the neighbouring countries inhabited by Romanians", it was becoming clear that ethnographic maps were also needed. There was a rush to create ethnographic maps between 1914 and 1916 . Their titles reveal that they are an ethnographic adaptation of the more traditional map of countries inhabited by Romanians.

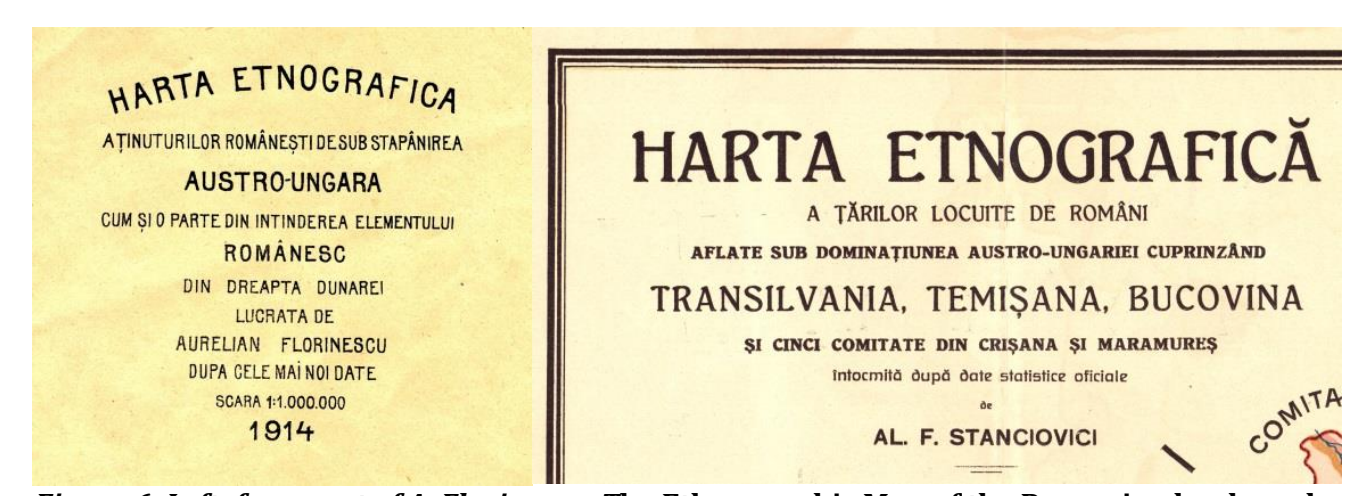

Figure 6. Left: fragment of A. Florinescu, The Ethnographic Map of the Romanian lands under the dominion of Austro-Hungary as well as a part of the spread of the Romanian element on the right side of the Danube, 1914. Right: fragment of F. Stanciovici, The Ethnographic map of the Countries inhabited by Romanians under the dominion of Austro-Hungary including Transylvania, Temisana, Bucovina and five Counties from Crisana and Maramures.

In 1914 Aurelian Florinescu published a map of Romanian lands, a term very similar to country. It is 'a map of countries inhabited by Romanians' transformed into an ethnographic one. We know very little about Florinescu except that he published an article on the geography of Ploiesti in 1915. The map claimed to be drawn after 'the newest data', but it is clear from the map that Florinescu interpreted these data heavily in favour of Romanians. The map also includes the categories of 'MaghiarizedRomanians' and 'Ruthenized-Romanians', again pointing to the past rather than the present.

Florian Stanciovici, a jurist from Craiova, published a map of Romanian countries in 1915, listing them in detail: Transylvania, Temișana (Banat), Bucovina and five counties of Crișana and Maramureș. The term 'country' again means province. By choosing to depict only those counties of Crisana and Maramures 'inhabited by Romanians', the map follows Brătianu's choices in the negotiations with the allies. 


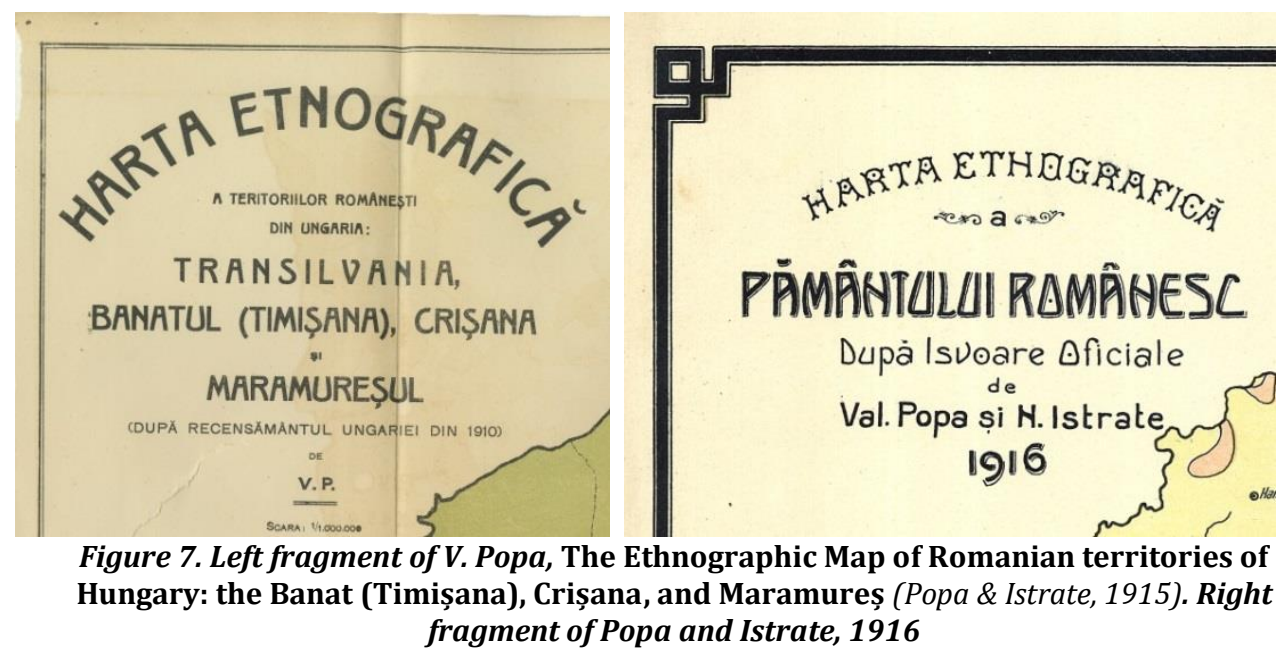

In 1915 Valentin Popa published a map of Romanian territories in Hungary (Figure 7). He was a statistician and economist. Popa mentions them by name: the Banat, Crișana and Maramureș. All of Maramureș is included in the map, but Bucovina, not part of the crown of Hungary, was not mentioned. This 1915 map depicts all the area West until the Tissa. In 1916 he published a new version of the map, which included some changes from the first version. Bucovina and Bessarabia were included as well, but only the Southern half of Maramureș, on the right bank of the Tissa. The shift between 1915 and 1916 is that of shifting from the maximalist claims of Dacia to those from the BrătianuSazonov negotiations.

\section{Conclusions}

Altogether the maps discussed so far show a high degree of uniformity. Behind them, there is a coherent understanding of both history and ethnography. This construct was characteristic of Romanian culture but, at the same time, it was different from the rising field of ethnographic cartography. The concept of 'countries inhabited by Romanians' was as much founded in the historical construct as in present-day ethnographic realities. It is, therefore, not difficult to see why these maps, seen from a Western perspective, were regarded as unscientific. In Romanian historiography, it is often said that Romania went to war for the territories inhabited by Romanians. This simplification hides a much more complex truth. The concept of 'countries inhabited by Romanians' was, in fact, the cultural construct in Romanian society.

These maps also allow us to witness a transition. The appearance of better and much more complex ethnographic maps, as well as ever closer contact with Western scholars, was changing Romanian cartography. Already the negotiations to enter the war shifted from the borders of Dacia to more modest requests. The negotiations are perhaps the moment when Romanian culture constructed its own geography, which mattered most as it came under scrutiny from a wide variety of scholars, diplomats, and politicians. The result was inevitably a compromise that did not satisfy everyone. A part of Romanian society was dissatisfied with the borders of 1919 because they fell short of the borders of ancient - and modern - Dacia. This trait of Romanian culture did not disappear. Even today the concept of Dacia is still present. Students are bombarded with waves of maps framed by the Tissa and the Dniester. A wider discussion of the cartography of Dacia in Romanian society is still, today, a subject of great importance. 


\section{References}

Ablonczy, B. (2007). Pál Teleki (1874-1941): The Life of a Controversial Hungarian Politician, Centre for Hungarian Studies and Publications.

Albrecht-Carrié, R. (1938). Italy at the Peace Conference, Archon Books.

An. (1919). Mémoire présenté par la délégation roumaine: La Roumanie devant le Congrès de la Paix [Brief presented by the Romanian delegation: Romania before the Peace Congress]. In AMAE, Recueil des Actes de la Conférence de la Paix, IV, C.

An. (1920). Geography at the Congress of Paris, 1919. Geographical Journal, 55, 309-312.

Anghel, S. (2021). N. Mazere and the first Romanian ethnographic map of Transylvania. forthcoming.

Antonescu, I. (1919). Românii: originea, trecutul, sacrificiile și drepturile lor [Romanians: the origin, the past, their sacrifices and their rights], Bucharest.

Bariéty, J. (1996). Le Comité d'Etudes du Quai d'Orsay et les frontières de la Grande Roumanie, 1918-1919 [The Study Committee of the Quai d'Orsay and the borders of Greater Romania, 1918-1919]. Revue Roumaine d'histoire, XXXV(1-2), Jan.-Jun., 43-52.

Bariéty, J. (1997). Le géographe Emmanuel de Martonne, médiateur entre la Roumanie et la France [The geographer Emmanuel de Martonne, mediator between Romania and France]. Etudes Danubiennes, XIII(2), 25-33.

Boulineau, E. (2001a). Les géographes et les frontières austro-slovènes des Alpes orientales en 1919-1920: entre la Mitteleuropa et les Balkans [The geographers and the Austro-Slovenian borders of the Eastern Alps in 1919-1920: between Mitteleuropa and the Balkans]. Revue de Géographie Alpine, 4, 173-184. http://www.persee.fr/doc/rga_0035-1121_2001_num_89_4_3064

Boulineau, E. (2001b). Un géographe traceur de frontières: Emmanuel de Martonne et la Roumanie [A geographer tracing borders: Emmanuel de Martonne and Romania]. L'Espace géographique, 4, 358-369. http://www.cairn.info/revueespace-geographique-2001-4-page-358.html

Boulineau, E. (2008). Fronts et frontières dans les Balkans: les géographes et les enjeux frontaliers sur le Danube en 1919-1920 [Fronts and borders in the Balkans: geographers and border issues on the Danube in 1919-1920]. Balkanologie, X(1-2), May. http://balkanologie.revues.org/396

Bowd, G. (2011). Emmanuel de Martonne et la naissance de la Grande Roumanie [Emmanuel de Martonne and the birth of Greater Romania]. Revue Roumaine de géographie, 55(2), 103-120.

Bowd, G. (2012). Un géographe français et la Roumanie. Emmanuel de Martonne (18731955) [A French geographer and Romania. Emmanuel de Martonne (1873-1955)], L'Harmattan.

Bowman, I. (1921). The New World, Problems of Political Geography, World Book Company.

Colescu, L. (1913). Naționalitățile din Dobrogea după recensământul general al populațiunii din 19 decembrie/1 ianuarie 1913, 1:200.000 [Nationalities in Dobroudja according to the general population census of December 19 / January 1, 1913, 1: 200,000], Bucharest, Lit. Göbl-Rasidescu.

Coman, M. (2006). Spaţiul românesc. Interpretarea teleologica a geografie istorice [The Romanian space. Teleological interpretation of historical geography]. Revista istorică, 17(2006), 52-59.

Crampton J. W. (2006). The cartographic calculation of space: race mapping and the Balkans at the Paris Peace Conference of 1919. Social \& Cultural Geography, 7(5), 731-752.

Cvijić, J. (1918). La Péninsule balkanique, géographie humaine [The Balkan Peninsula, human geography], Armand Colin.

Cvijić, J. (1919). La frontière septentrionale des Yougoslaves [The Northern border of the Yugoslavs], Lahure. 
Délégation des Serbes, Slovènes et Croates [n.d., 1919?a], Frontiers between the Kingdom of the Serbians, Croatians and Slovenes and the Kingdom of Italy [rapport].

Densuşianu, N., \& Damé, F. (1877). Les Roumains du Sud Macédoine. Thessalie, Epire, Thrace, Albanie. Avec une carte ethnographique [The Romanians of Southern Macedonia. Thessaly, Epirus, Thrace, Albania. With an ethnographic map], Bucarest, F. Göbl.

Florinescu, A. (1914). Harta etnografică a ținuturilor Românești de sub stăpânirea Austro-Ungară cum și parte din întinderea elementului Românesc din dreapta Dunarei lucrată de Aurelian Florinescu dupa cele mai noi date, 1:1.000.000 [Ethnographic map of the Romanian lands under Austro-Hungarian rule as part of the extent of the Romanian element on the right bank of the Danube made by Aurelian Florinescu according to the latest data, 1: 1,000,000], Bucharest.

Ginsburger, N. (2010). «La guerre, la plus terrible des érosions». Cultures de guerre et géographes universitaires, France-Allemagne-Etats-Unis (1914-1921) ["War, the most terrible of erosions." War Cultures and University Geographers, FranceGermany-USA (1914-1921)], Ph.D. thesis, Université de Paris Ouest Nanterre-La Défense. http://bdr.u-paris10.fr/theses/internet/2010PA100195.pdf

Ginsburger, N. (2015a). Les Balkans avec ou sans Cvijić. Géographes et géologues universitaires austro-allemands, français et serbes dans un espace européen périphérique (1893-1934) [The Balkans with or without Cvijić. Austro-German, French and Serbian university geographers and geologists in a peripheral European space (1893-1934)]. In P. Clerc \& M.-C. Robic (Eds.), Des géographes hors-les-murs? Itinéraires dans un Monde en mouvement (1900-1940) [Geographers outside the walls? Itineraries in a Moving World (1900-1940)] (pp. 323-354), L'Harmattan.

Ginsburger, N. (2015b). André Chéradame et l'émergence d'une cartographie géopolitique de guerre en 1916 [André Chéradame and the emergence of a geopolitical map of war in 1916]. Cartes \& Géomatique, 223, March, special issue14/18: La Guerre en cartes , 79-90.

Ginsburger, N. (2016a). L'expertise territoriale et cartographique des vaincus austrohongrois. Robert Sieger, Pál Teleki et les traités de Saint-Germain et de Trianon [The territorial and cartographic expertise of the defeated Austro-Hungarians. Robert Sieger, Pál Teleki and the Treaties of Saint-Germain and Trianon]. Cartes \& Géomatique, 228.

Ginsburger, N. (2016b). Réseaux académiques et circulations savantes entre guerres et paix (1912-1919). Les expertises de Jovan Cvijić et de ses collègues géographes à travers les cas de Trieste et Fiume [Academic networks and scholarly circulations between wars and peace (1912-1919). The expertise of Jovan Cvijić and his fellow geographers through the cases of Trieste and Rijeka]. Cybergeo: European Journal of Geography, 784. https://journals.openedition.org/cybergeo/27690\#bodyftn22

Hallair, G. (2007). Le géographe Emmanuel de Martonne et l'Europe Centrale, Prodig, Grafigéo, 33.

Harley, J. B. (2001). The New Nature of Maps: Essays in the History of Cartography. Johns Hopkins University Press.

Lederer, I. J. (1963). Yugoslavia at the Paris Peace Conference. A Study in Frontiermaking, Yale University Press.

de Martonne, E. (1915a). La Roumanie et son rôle dans l'Europe orientale [Romania and its role in Eastern Europe]. La Géographie. Bulletin de la Société de Géographie, 1914-1915, 241-250.

de Martonne, E. (1915b). Les conditions d'une intervention roumaine [The conditions of a Romanian intervention]. Revue de Paris, XXII, 10, May15, 430.

de Martonne, E. (1919). Repartition des Nationalites dans les Pays ou ils dominent les Roumains, 1:1 000000 [Distribution of Nationalities in the Countries where they dominate the Romanians, 1: 1,000,000]. In E. de Martonne, Travaux $d u$ Comite d'etudes, tome II, Questions europeennes, Atlas (Paris, Service Geographique de l'Armee, 1919). 
Mazere, N. (1909a). Harta Etnografică a Transilvaniei, 1:340.000 [Ethnographic Map of Transylvania, 1: 340,000]. Iasi, Army Geographic Service.

Mazere, N. (1909b). Supliment la harta etnografică a Transilvaniei [Supplement to the ethnographic map of Transylvania], Iasi, H. Goldner.

Meruțiu, V. (1919a). România dintre Tisa şi Carpați: Transilvania, Maramurășul, Țara Crișului și Bănatul: hartă etnografică, 1:800.000 [Romania between the Tisza and the Carpathians: Transylvania, Maramurăș, Țara Crișului and Bănatul: ethnographic map, 1: 800.000]. Iasi, Army Geographic Service.

Meruțiu, V. (1919b). România Dintre Tisa și Carpați Transilvania, Maramurăsul, Țara Crisului şi Bănatul. Hartă etnografică, București, Serviciul Geografic al Armatei, 1919. 28 de foi, 1:200.000 [Romania Between the Tisza and the Carpathians Transylvania, Maramurăsul, Țara Crisului and Bănatul. Ethnographic map, Bucharest, Geographical Service of the Army, 1919. 28 sheets, 1: 200,000].

Murgoci, G. M., \& Popa-Burcă, I. (1902). România și țerile locuite de români [Romania and the countries inhabited by Romanians], $1^{\text {st }}$ edition, Göbl-Rasidescu.

Murgoci, G. M. \& Popa-Burcă, I. (1914). România și țerile locuite de români [Romania and the countries inhabited by Romanians], ${ }^{\text {th }}$ edition, Göbl-Rasidescu.

Nicolson, H. (1933/1966). Peacemaking 1919, Constable/ Grosset \& Dunlap.

Nour, A. (1915). Basarabia. Harta Etnografică [Bessarabia. Ethnographic Map], drawn by Trayan Georgescu, C. Ioanid and Al. Nor, approx. 1:450.000, Lit. Göbl-Rasidescu.

Palsky, G. (2002). Emmanuel de Martonne and the Ethnographical Cartography of Central Europe (1917-1920). Imago Mundi, 54, 111-119.

Palsky, G. (2015). Martonne, Emmanuel de. In M. S. Monmonier (Ed.), Cartography in the Twentieth Century, vol. 6, The History of Cartography (pp. 864-867), University of Chicago.

Popa, V., \& Istrate, N. (1915). Situaţia Economică şi Culturală a teritoriilor româneşti din Ungaria, Crişana şi Maramureşul. Cu o hartă etnografică, de Valeriu Popa şi Nicolae Istrate [Economic and Cultural Situation of the Romanian territories in Hungary, Crişana and Maramureș. With an ethnographic map, by Valeriu Popa and Nicolae Istrate].Tip. Curţii Regale, F. Göbl Fii.

Popa, V., \& Istrate, N. (1916). Harta etnografică a pămîntului românesc. 1) Transilvania. 2) Banatul. 3) Crişana. 4) Maramurăşul. 5) Bucovina. 6) Basarabia. 7) Moldova. 8) Muntenia. 9) Oltenia. 10) Dobrogea [de] Val. Popa şi N. Istrate. Insoţită de tabele statistice privitoare la suprafaţă, populaţie, agricultură, mine, administraţie şi căi de comunicație [Ethnographic map of the Romanian land. 1) Transylvania. 2) Banat. 3) Crişana. 4) Maramurăşul. 5) Bucovina. 6) Bessarabia. 7) Moldova. 8) Muntenia. 9) Oltenia. 10) Dobrogea [de] Val. Popa and N. Istrate. Accompanied by statistical tables on area, population, agriculture, mines, administration and means of communication], Tip. Energiea.

Prévélakis, G. (2000). Le géographe serbe Jovan Cvijić et la "guerre des cartes" macédonienne. In D. Balland (Ed.), Hommes et Terres d'Islam (mélanges offerts à Xavier de Planhol) (vol. II, pp. 257-276), Institut français de recherche en Iran.

Recueil général des Actes de la Conférence de la paix (1923). Partie IV-C, Questions territoriales, Commission des Affaires roumaines et yougoslaves, Paris, Imprimerie nationale.

Sandu, T. (2006). Les relations roumano-serbes et la question du Banat durant la Première Guerre mondiale [Romanian-Serbian relations and the Banat issue during the First World War]. Balcanica, XXXVII, 241-246.

Seton-Watson, H., \& Seton-Watson, C. (1981). The Making of a New Europe: R.W. SetonWatson and the Last Years of Austria-Hungary, Taylor \& Francis.

Société de géographie de Paris (2015). Les experts français et les frontières d'aprèsguerre. Les procès-verbaux du comité d'études 1917-1919, introduction et notes par I. Davion, préface de G.-H. Soutou. Supplément au Bulletin de liaison des membres de la Société de Géographie, June.

Spector, S. D. (1995). Romania at the Paris Peace Conference: A Study of the Diplomacy of Ioan I.C. Brãtianu, Center for Romanian Studies.

Stanciovici, F. (1915). Harta etnografică a țărilor locuite de români aflate sub dominațiunea Austro-Ungariei cuprinzând Transilvania, Temișana, Bucovina și 
cinci comitate din Crișana și Maramureș [Ethnographic map of the countries inhabited by Romanians under the domination of Austria-Hungary including Transylvania, Temișana, Bucovina and five counties in Crișana and Maramureș],Institutul de editură Samitca

Suveica, S. (2017). Between Science, Politics and Propaganda, Emmanuel de Martonne and the debates on the status of Bessarabia (1919 1920). Cahiers du monde russe, 58(4), 589-614.

Ter Minassian, T. (1997). Les géographes français et la délimitation des frontières balkaniques à la Conférence de la paix en 1919 [French geographers and the delimitation of the Balkan borders at the 1919 Peace Conference]. Revue d'histoire moderne et contemporaine, 44(2), 252-286.

Ter Minassian, T. (2002). Les géographes français et la délimitation des frontières de la Bulgarie à la Conférence de la paix en 1919 [French geographers and the delimitation of Bulgaria's borders at the 1919 Peace Conference]. Balkanologie, VI(1-2), 199-212.

White, G. W. (2000). Nationalism and territory, Constructing Group Identity in Southeastern Europe, Rowman \& Littlefield.

Wild, J., Wild, A., \& Ardeleanu, C. (2018). Jurnalul călătoriei lui Alexandru Lăpedatu către Paris (decembrie 2018) pentru participarea la conferința de pace de la finalul primului război mondial [The diary of Alexandru Lăpedatu's trip to Paris (December 2018) to participate in the peace conference at the end of the First World War]. Analele Universităţii „Dunărea de Jos” din Galaţi, Seria 19, Istorie, tom XVII, 41-52.

Wild, J. (2018). Traversând frontiere: exemplul fraților Lapedatu [Crossing borders: the example of the Lapedatu brothers], conference at NEC, Bucharest. http://www.lapedatu.com/wp-content/uploads/2019/03/Traversândfrontiere.pdf

Wilkinson, H. R. (1951). Maps and Politics. A Review of the Ethnographic Cartography of Macedonia, Liverpool University Press.

\begin{abstract}
Author biography
Dr. Silviu Anghel has been trained as a historian of the Greco-Roman World. He took his MA at the University of Bucharest and his doctorate at the University of Columbia in New York. Besides his work on the Late Roman Empire, he is also working on the history of cartography. He was a fellow of the American Academy in Rome, the American School in Athens, as well as of the Center for Eastern Mediterranean Studies in Istanbul. He worked also at the Gottingen University, at EDRIS Center, as well as the National Museum of Maps and Old Books.
\end{abstract}

